\title{
Rickettsiae-infected Ticks in an Endemic Area of Spotted Fever in the State of Minas Gerais, Brazil
}

\author{
Elba Regina Sampaio de Lemos/ ${ }^{+}$, Raimundo Diogo Machado*, Fernando \\ Dias de Ávila Pires, Sérgio Lisboa Machado*, Lígia Maria Cantarino da Costa, \\ José Rodrigues Coura
}

\begin{abstract}
Departamento de Medicina Tropical, Instituto Oswaldo Cruz, Av. Brasil 4365, 21045-900 Rio de Janeiro, RJ, Brasil *Departamento de Virologia, Instituto de Microbiologia, Universidade Federal do Rio de Janeiro, Cidade Universitária, 21941-590 Rio de Janeiro, RJ, Brasil

A study on tick-borne rickettsiosis was developed in the county of Santa Cruz do Escalvado, State of Minas Gerais, Brazil, where a clinical case of the disease, confirmed by necropsy, had been reported. Of the 1,254 ticks collected, 1,061 belonged to the Amblyomma genus, 57 to the Rhipicephalus sanguineus species, 81 to Boophilus microplus, and 46 to Anocentor nitens. The hemolymph test associated with Giménez staining showed that 18 of the 221 A. cajennense specimens, 1 of the $16 \mathrm{R}$. sanguineus, 1 of the 22 B. microplus, 3 of the A. nitens, and 1 of the A. ovale contained rickettsia-like microorganisms. Only 3 A. cajennense ticks were positive under direct immunofluorescence. A. cajennense was the only species found on humans.
\end{abstract}

Key words: spotted fever - ticks - hemolymph test - Brazil

In Brazil, Amblyomma cajennense is considered the most important vector for Rickettsia rickettsii, the causal agent for Brazilian spotted fever. This tick species is widely distributed in Brazil and is frequently found infesting human beings.

Although few studies have been performed on this subject, there has been an increase in case reports of this rickettsiosis in southeastern Brazil, including the states of Minas Gerais, São Paulo, Rio de Janeiro, and Espírito Santo (Gonçalves et al. 1977, 1981, Sampaio et al. 1988, Souza et al. 1991, Sexton et al. 1993).

This paper reports the prevalence of rickettsiainfected ticks in an endemic area where a fatal clinical case confirmed by necropsy had been reported (Lemos et al. 1994). A five-year-old child died after a tick bite presenting fever, chills, widespread maculopapular rash, and encephalopathy.

\section{MATERIALS AND METHODS}

The village of Patrimônio, from where the index case came, and other eigth localities, were selected in the county of Santa Cruz do Escalvado

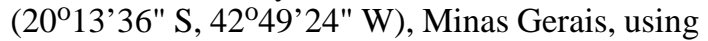
as reference the geographical coordinates. It was

Supported by CAPES and FIOCRUZ.

${ }^{+}$Corresponding author. Fax:+55-21-280.3740

Received 19 December 1996

Accepted 22 May 1997 thus possible to show areas with different geographic characteristics, in addition to differences in soil manegment and population density. The human population was higher in Patrimônio, São José de Vargem Alegre, Merengo, Zito Soares and Soberbo than in other villages chosen for this study (Fig.).

Patrimônio (1) and São José de Vargem Alegre - Sites with human settlements, where crop fields have been abandoned and turned into pasture, with virtually no farming activity other than cattle-raising.

Empreitada (3), Merengo (2), and Gambá (7) Sites along Rio Doce with various crop areas (corn, sugar cane, beans), where slashing and burning is common.

Zito Soares (4), Pedreira (5), and Facão (8) Sites away from the banks of Rio Doce, with numerous abandoned crop fields and clumps of primary forest growth.

Soberbo (6) - A site near Rio Doce with no crop or pasture areas. The vegetation of this area consisted of secondary vegetation.

With the help of a veterinarian, 1,254 ticks were colected during seven field visits at 2-3 months intervals from July 1989 to November 1990. Feeding ticks were removed from theirs hosts (human and domestic animals) and free-living ticks were colected from vegetation, near human settlements, using a flannel cloth.

After taxonomic identification (Rohr 1909, Aragão \& Fonseca 1961) only a group of ticks was 


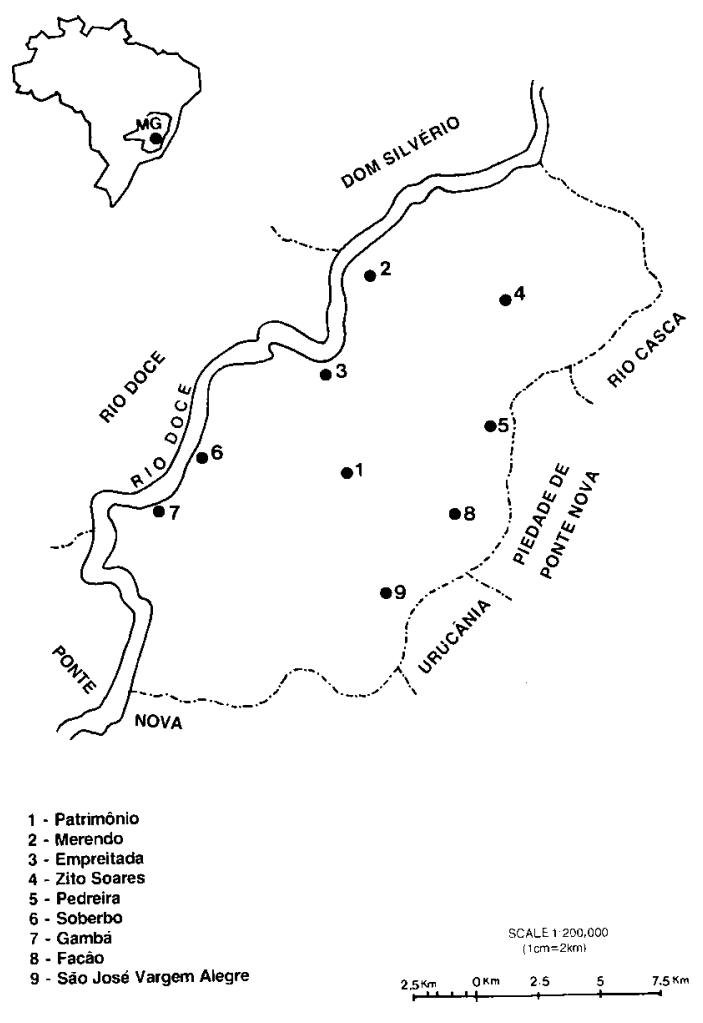

Santa Cruz do Escalvado, county limits, and locations studied. submitted to hemolimph test (Burgdorfer 1970) because the other, mainly the immature stages, was carried to taxonomic confirmation in the Departament of Entomology at the Oswaldo Cruz Institute.

The ticks were disinfected with $4 \%$ formaldehyde solution, $3 \%$ hydrogen peroxide, and $70 \%$ alcohol and washed in sterile distilled water for 5 min.

For each live tick, two slides were prepared with the hemolymph, fixed in acetone for $15 \mathrm{~min}$. The first was to investigate rickettsia-like microorganisms using Giménez staining, and the second to perform the direct immunofluorescence test with $R$. rickettsii-positive human serum and fluorescein.

\section{RESULTS}

The tick species collected in this study and their distribution in relation to locations and food sources are shown in Tables I and II. Of the 1,254 ticks collected from animals, human beings, and vegetation, A. cajennense was the predominant species.

All the ticks taken from human beings belonged to the nymphal stage of $A$. cajennense and came from Patrimônio.

Of the 1,254 ticks collected, only 514 were submitted to the hemolymph test with Giménez staining, and of these, 24 displayed intracellular particles in the hemocytes. These rickettsia-like

TABLE I

Tick collected at nine study sites in the county of Santa Cruz do Escalvado, State of Minas Gerais, Brazil (1989-1990)

\begin{tabular}{|c|c|c|c|c|c|c|c|c|c|c|c|c|c|c|c|c|c|c|c|}
\hline \multirow[b]{3}{*}{ Location } & \multicolumn{18}{|c|}{ Tick species } & \multirow[b]{3}{*}{ Total } \\
\hline & \multicolumn{3}{|c|}{ Ac } & \multicolumn{3}{|c|}{ Rs } & \multicolumn{3}{|c|}{$\mathrm{Bm}$} & \multicolumn{3}{|c|}{ An } & \multicolumn{3}{|c|}{ Ao } & \multicolumn{3}{|c|}{ Total } & \\
\hline & $\mathrm{L}$ & $\mathrm{N}$ & A & $\mathrm{L}$ & $\mathrm{N}$ & A & $\mathrm{L}$ & $\mathrm{N}$ & $\mathrm{A}$ & $\mathrm{L}$ & $\mathrm{N}$ & A & $\mathrm{L}$ & $\mathrm{N}$ & A & $\mathrm{L}$ & $\mathrm{N}$ & A & \\
\hline Patrimônio & 657 & 78 & 44 & 0 & 0 & 0 & 0 & 0 & 19 & 0 & 0 & $J$ & 0 & 0 & 0 & 657 & 78 & 66 & 801 \\
\hline Empreitada & 0 & 2 & 0 & 0 & 0 & 0 & 0 & 0 & 1 & 0 & 0 & 0 & 0 & 0 & 0 & 0 & 2 & 1 & 3 \\
\hline Merengo & 0 & 17 & 4 & 0 & 0 & 0 & 0 & 0 & 30 & 0 & 0 & 0 & 0 & 0 & 0 & 0 & 17 & 34 & 51 \\
\hline Z. Soares & 0 & 48 & 24 & 0 & 0 & 0 & 0 & 0 & 1 & 0 & 0 & 41 & 0 & 0 & 0 & 0 & 48 & 66 & 114 \\
\hline Pedreira & 0 & 5 & 29 & 0 & 0 & 0 & 0 & 0 & 0 & 0 & 0 & 0 & 0 & 0 & 0 & 0 & 5 & 29 & 34 \\
\hline Soberbo & 0 & 6 & 10 & 0 & 0 & 0 & 0 & 0 & 20 & 0 & 0 & 0 & 0 & 0 & 0 & 0 & 6 & 30 & 36 \\
\hline Gambá & 0 & 16 & 0 & 0 & 0 & 0 & 0 & 0 & 0 & 0 & 0 & 0 & 0 & 0 & 0 & 0 & 16 & 0 & 16 \\
\hline S. José & 0 & 9 & 2 & 0 & 0 & 57 & 0 & 0 & 10 & 0 & 0 & 2 & 0 & 0 & 0 & 0 & 9 & 71 & 80 \\
\hline Facão & 0 & 117 & 1 & 0 & 0 & 0 & 0 & 0 & 0 & 0 & 0 & 0 & 0 & 0 & 1 & 0 & 117 & 2 & 119 \\
\hline tal & 6 & 298 & 11 & 0 & 0 & 57 & 0 & 0 & 01 & 0 & 0 & 40 & 0 & 0 & 1 & 65 & 298 & 299 & 1,254 \\
\hline
\end{tabular}

Ac: Amblyomma cajennense, Rs: Rhipicephalus sanguineus, Bm: Boophilus microplus, An: Anocentor nitens, Ao: Amblyomma ovale, L: larvae, N: nymph, A: adult. 
TABLE II

Distribution of Amblyomma cajennense ticks by source of collection at nine study sites in the County of Santa Cruz do Escalvado, State of Minas Gerais, Brazil (1989-1990)

\begin{tabular}{lrrrrrr}
\hline & \multicolumn{6}{c}{ Source of collection } \\
\cline { 2 - 7 } Location & Human & Dog & Equine & Bovine & Vegetation & Total (\%) \\
\hline Patrimônio & 16 & 34 & 59 & 0 & 670 & $779(72.9)$ \\
Empreitada & 0 & 2 & 0 & 0 & 0 & $2(0.19)$ \\
Merengo & 0 & 17 & 4 & 0 & 0 & $21(1.96)$ \\
Zito Soares & 0 & 46 & 19 & 0 & 7 & $72(6.73)$ \\
Pedreira & 0 & 5 & 17 & 0 & 12 & $34(3.18)$ \\
Soberbo & 0 & 4 & 7 & 0 & 5 & $16(1.49)$ \\
Gambá & 0 & 16 & 0 & 0 & 0 & $16(1.49)$ \\
São José & 0 & 7 & 0 & 0 & 4 & $11(1.03)$ \\
Facão & 0 & 117 & 0 & 0 & 1 & $118(11.0)$ \\
\hline Total $(\%)$ & $6(0.56)$ & $248(23.2)$ & $106(9.9)$ & $0(0.0)$ & $699(65.4)$ & $1,069(100)$ \\
\hline
\end{tabular}

particles were observed invading the nucleus of the hemocyte in some specimens, suggesting spotted fever group rickettsiae (Table III).

The species displaying positive results under Giménez staining were: A. cajennense (18); $A$. nitens (3); R. sanguineus (1); B. microplus (1); and A. ovale (1).

Prevalence of infection in the ticks as deter- mined by Giménez staining was $8.1 \%$, considering that hemocytes were not observed in 218 ticks, meaning that the latter were not included in computing the results of this analysis (Table III).

Only three specimens of A. cajennense (adults) prepared with Giménez staining reacted to the conjugate with antibody for $R$. rickettsii, and all had been collected at Patrimônio.

\section{TABLE III}

Results of hemolymph test for tick species collected at nine study sites in the county of Santa Cruz do Escalvado, State of Minas Gerais, Brazil (1989-1990)

\begin{tabular}{|c|c|c|c|c|c|c|c|c|c|c|c|c|c|c|c|c|c|c|}
\hline \multirow[b]{3}{*}{ Location } & \multicolumn{18}{|c|}{ Tick species } \\
\hline & \multicolumn{3}{|c|}{ Ac } & \multicolumn{3}{|c|}{ Rs } & \multicolumn{3}{|c|}{$\mathrm{Bm}$} & \multicolumn{3}{|c|}{ An } & \multicolumn{3}{|c|}{ Ao } & \multicolumn{3}{|c|}{ Total } \\
\hline & $\mathrm{P}$ & $\mathrm{N}$ & $\mathrm{L}$ & $\mathrm{P}$ & $\mathrm{N}$ & $\mathrm{L}$ & $\mathrm{P}$ & $\mathrm{N}$ & $\mathrm{L}$ & $\mathrm{P}$ & $\mathrm{N}$ & $\mathrm{L}$ & $\mathrm{P}$ & $\mathrm{N}$ & $\mathrm{L}$ & $\mathrm{P}(\%)$ & $\mathrm{N}$ & $\mathrm{L}$ \\
\hline Patrimônio & 13 & 52 & 31 & 0 & 0 & 0 & 0 & 2 & 17 & 0 & 2 & 1 & 0 & 0 & 0 & $13(18.84)$ & 56 & 49 \\
\hline Empreitada & 0 & 1 & 1 & 0 & 0 & 0 & 0 & 1 & 0 & 0 & 0 & 0 & 0 & 0 & 0 & $0(0.00)$ & 2 & 1 \\
\hline Merengo & 0 & 15 & 6 & 0 & 0 & 0 & 0 & 3 & 27 & 0 & 0 & 0 & 0 & 0 & 0 & $0(0.00)$ & 18 & 33 \\
\hline Z. Soares & 3 & 33 & 17 & 0 & 0 & 0 & 0 & 1 & 0 & 3 & 31 & 7 & 0 & 0 & 0 & $6(8.45)$ & 65 & 24 \\
\hline Pedreira & 0 & 19 & 3 & 0 & 0 & 0 & 0 & 0 & 0 & 0 & 0 & 0 & 0 & 0 & 0 & $0(0.00)$ & 19 & 3 \\
\hline Soberbo & 0 & 5 & 0 & 0 & 0 & 0 & 0 & 10 & 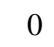 & 0 & 0 & 0 & 0 & 0 & 0 & $0(0.00)$ & 15 & 0 \\
\hline Gambá & 0 & 8 & 8 & 0 & 0 & 0 & 0 & 0 & 0 & 0 & 0 & 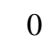 & 0 & 0 & 0 & $0(0.00)$ & 8 & 8 \\
\hline S. José & 0 & 6 & 5 & 1 & 15 & 41 & 1 & 4 & 2 & 0 & 0 & 2 & 0 & 0 & 0 & $2(7.40)$ & 25 & 50 \\
\hline Facão & 2 & 64 & 50 & 0 & 0 & 0 & 0 & 0 & 0 & 0 & 0 & 0 & 1 & 0 & 0 & $3(4.47)$ & 64 & 50 \\
\hline Total & 18 & 200 & 121 & 1 & 15 & 41 & 1 & 21 & 46 & 3 & 33 & 10 & 1 & 0 & 0 & $24(8.10)$ & 272 & 218 \\
\hline
\end{tabular}

Ac: Amblyomma cajennense,Rs: Rhipicephalus sanguineus, Bm: Boophilus microplus, An: Anocentor nitens, Ao: Amblyomma ovale, $\mathrm{P}$ : positive, N: negative, L: material lost 


\section{DISCUSSION}

The ixodid fauna in this study presented only five species. A. cajennense, although also found in equines, bovines, and the vegetation, was the only species found in human beings. This finding stresses the importance of this species in spotted fever ecology in Brazil, a fact that has been well documented by various Brazilian researchers (Fonseca 1932, Monteiro \& Fonseca 1932, Moreira \& Magalhães 1937, Dias \& Martins 1939, Magalhães \& Moreira 1939, Travassos \& VallejoFreire 1944-45, Magalhães 1952).

A. cajennense was recovered in all studied areas but most of them were found in Patrimônio. It may probably be due to the great number of abandoned horses and dogs, the lack of control of tick infestation and the predominance of abandoned fields in this village.

Although they were not observed feeding on human beings, B. microplus, A. nitens, A. ovale, and $R$. sanguineus (the latter known as a vector for spotted fever caused by $R$. conori in Europe) may be implicated in maintaining spotted fever group rickettsiae in nature.

The infection frequency based on direct immunofluorescence was $1 \%$ for the 269 ticks examined, a result similar to that observed by Magnarelli et al. (1981) in Connecticut, USA. However, the various studies on prevalence of infection in ticks display wide variation, with prevalences ranging from $0.14 \%$ to $13.5 \%$, based on the areas studied or even the period within a given area (Burgdorfer et al. 1974, Sexton et al. 1976, Benach et al. 1977, Feng et al. 1980, Lane et al. 1981, Taylor et al. 1986).

Magnarelli et al. (1981) observed that the number of infected ticks detected by direct immunofluorescence did not vary when they compared those collected from what were considered endemic areas for the human disease and locations where spotted fever had never been reported. This may apparently invalidate the importance of infection in ticks as an indicator of rickettsial activity; however, we should not overlook that the presence of human cases is merely a biological accident, undoubtedly a poor and unreal indicator of precise spotted fever group rickettsiosis distribution in nature. Although the presence of infected ticks is necessary, it is not sufficient to produce human cases; presence of the latter basically provides a point of departure for studying the disease's epidemiology and ecology, in addition to fostering improved epidemiological surveillance.

\section{ACKNOWLEDGMENTS}

To Dr Bernardino C Albuquerque for discussing this study during the planning stage. To Prof. Rubens P Mello for assistance in tick identification. To Nilma P Gusmão for technical assistance, and Prof. Nicolau M Serra-Freire for discussing the manuscript.

\section{REFERENCES}

Aragão H, Fonseca F 1961. Notas de Ixodologia. VIII. Lista e chave para os representantes da fauna ixodológica brasileira. Mem Inst Oswaldo Cruz 59: 115-148.

Benach JL, White DJ, Burgdorfer W, Keelan T, Guirgis $\mathrm{S}$, Altiere H 1977. Changing patterns in the incidence of Rocky Mountain spotted fever on Long Island (1971-1976). Am J Epidemiol 106: 380-387.

Burgdorfer W 1970. Hemolymph test. A technique for detection of rickettsiae in ticks. Am J Trop Med Hyg 12: 1010-1014.

Burgdorfer W, Cooney JC, Thomas LA 1974. Zoonotic potential (Rocky Mountain spotted fever and tularemia) in the Tennessee Valley region. II. Prevalence of Rickettsia ricksettsii and Franciella tularensis in mammals and ticks from Land Between the Lakes. Am J Trop Med Hyg 23: 109-117.

Dias E, Martins AV 1939. Spotted fever in Brazil. A summary. Am J Trop Med 19: 103-108.

Feng WC, Murray ES, Burgdorfer W, Spielman JM, Rosemberg G, Dang K, Smith C, Spickert C, Waner JL 1980. Spotted fever group rickettsiae in Dermacentor variabilis from Cape Cod, Massachusetts. Am J Trop Med Hyg 29: 691-694.

Fonseca F 1932. Notas de acarologia. I. Papel dos acarinos do gênero trombicula na transmissão das rickettsias patogênicas e aplicação dessa hipótese à Rickettsia brasiliensis. Mem Inst Butantan 7: 129133.

Gonçalves AJR, Costa IC, Siqueira SMC, Pinto AMM, Melo JPC, Lazera MS 1977. Riquetsiose: a propósito de um caso. Rev Med HSE 29: 223-232.

Gonçalves AJR, Lopes PFA, Melo JCP, Pereira AA, Pinto AMM, Lazera MS, Sousa MLS, Teixeira CRU, Oliveira JC, Duarte F 1981. Rickettsioses: a propósito de quatro casos diagnosticados no Rio de Janeiro de febre maculosa. F Méd(Br) 82: 127 134.

Lane RS, Emmons RW, Dondero DV, Nelson BC 1981. Ecology of tick-borne agents in California. Am J Trop Med Hyg 30: 239-252.

Lemos ERS, Machado RD, Coura JR 1994. Rocky Mountain spotted fever in an endemic area in Minas Gerais, Brazil. Mem Inst Oswaldo Cruz 91: $497-$ 501.

Magalhães O 1952. Contribuição para o conhecimento das doenças do grupo do tifo exantemático. Monog. Inst Oswaldo Cruz, Rio de Janeiro, no. 6, 986 pp.

Magalhães O, Moreira JA 1939. Typho exanthemático em Minas Gerais. Epidemiologia. Brasil Médico 37: 882-891.

Magnarelli LA, Anderson JF, Philip RN, Burgdorfer W, Casper EA 1981. Endemicity of spotted fever group rickettsiae in Connecticut. Am J Trop Med Hyg 30: 715-721.

Monteiro JL, Fonseca F 1932. Typho exanthemático de São Paulo. XI. Novas experiências sobre a 
transmissão experimental por carrapatos (Boophilus microplus e Amblyomma cajennense). Mem Inst Butantan 7: 33-40.

Moreira JA, Magalhães O 1937. Typho exanthemático de Minas Gerais ( $7^{\mathrm{a}}$ comunicação). Brasil Médico 51: 388-392.

Rohr C 1909. Estudos sobre ixodidas do Brasil. Inst Oswaldo Cruz. Rio de Janeiro, 220 pp.

Sampaio CC, Ferreira RP, Patelli M, Provenza JR, Marques Neto JF, Samara AM 1988. Vaculite com gangrena dos artelhos em um paciente com riquetsiose. Rev Bras Med 45: 277-279.

Sexton DJ, Burgdorfer W, Thomas L, Norment BR 1976. Rocky Mountain spotted fever in Mississippi: survey for spotted fever antibodies in dogs and for spotted fever group rickettsiae in dog ticks. Am J Epidemiol 103: 192-197.

Sexton DJ, Muniz M, Corey GR, Breitschwerdt EB,
Hegarty BC, Dumler S, Walker DH, Peçanha PM, Dietz R 1993. Brazilian spotted fever in Espírito Santo, Brazil: description of a focus of infection in a new endemic region. Am J Trop Med Hyg 49: 222-226.

Souza MAA, Paula AB, Primo JDA, Ramos EP, Magalhães SA, Perpétuo AC 1991. Febre maculosa brasileira em Virginópolis - Minas Gerais. VI Congresso Brasileiro de Infectologia, Anais, p. 68.

Taylor AC, Hii J, Kelly DJ, Davis DR, Lewis GE 1986. A serological survey of scrub, tick, and endemic typhus in Sabah, East Malaysia, South Asia. J Trop Med Publ Hlth 17: 613-619.

Travassos J, Vallejo-Freire A 1944-1945. Criação artificial de Amblyomma cajennense para o preparo de vacina contra a febre maculosa. Mem Inst Butantan 18: $147-235$. 
482 Rickettsiae-infected Ticks in the State of Minas Gerais, Brazil • ERS de Lemos et al. 